\title{
On the Support of Air Traffic Control in Anti - terrorism Operation in the Northwest
}

\author{
Jianbo Wang ${ }^{\text {a }}$, Haolin Cui and Jiangbin Dai \\ Air Traffic Control College, Air Force Engineering University, Xi'an 710051, China \\ ajianbowang2008@163.com
}

\begin{abstract}
As the terrorist activities in the northwest of China becoming increasingly harmful to our society,the tactical issue of anti-torrorism there has turned to be strategical.On the basis of summarizing the strategic position and the current situation of anti-terrorism in northwest, this paper generalizes the main tasks of anti-terrorism operations and air traffic control in the northwest direction, analyzes the characteristics and requirements of air traffic control, puts forward four aspects of countermeasures from the organizational system, operating mechanism, regulatory standards and technology of equipment to strengthen air traffic control capability of anti - terrorism operations in the northwest direction.
\end{abstract}

Keywords: northwest direction; counter-terrorism operations; air traffic control support; countermeasures

\section{西北方向反恐作战空管保障问题初探}

\author{
王建波, 崔浩林, 戴江斌 \\ 空军工程大学空管领航学院, 西安, 中国
}

摘要: 随着西北方向恐怖活动对我国社会的危害性越来越大, 西北方向反恐已由一个战术性 问题上升为一个战略性问题。该文在全面总结西北地区战略地位和当前反恐形势的基础上, 归纳了西北方向反恐作战及空管保障主要任务, 分析了空管保障的特点和要求, 从组织体系、 运行机制、法规标准和技术装备四个方面提出加强西北方向反恐作战空管保障能力的对策思 考。

关键词：西北方向；反恐作战；空管保障；对策思考

\section{1. 前言}

在美国 “重返亚太”，或明或暗煽动周边国家对我东海、南海方向实施战略围堵的情况下, 加紧西北方向战略运筹显得尤为重要。西北地区自然环境恶劣, 社情民情复杂, 历来是恐怖 主义滋长之地, 随着 “伊斯兰国”、“前进阵线” 等新兴恐怖组织渐成气候, 西北地区恐怖 势力也蚌蚌欲动, 妄图制造骚乱破坏。目前, 西北方向反恐作战研究主要集中在陆军、武警、 警察力量运用和战法研究上, 对空中力量运用研究较少, 对空中力量反恐作战空管保障问题 的研究更少。由于自然、社会和历史等因素的影响, 西北地区空管发展水平相对滞后, 空管 组织体系不清、运行机制不畅、法规标准不全、技术装备不新等矛盾问题凸显, 空管保障能 力与当前反恐使命任务已不相适应, 迫切需要加以改进。全面归纳西北方向反恐作战空管保 障任务, 分析空管保障的特点和要求, 提出合理化对策建议, 既能丰富反恐作战空管理论体 系，又可以为一线管制人员反恐作战实践提供有益参考。 


\section{2. 西北方向反恐作战及空管保障主要任务}

2.1 西北方向反恐作战

随着国际战略格局和我国周边安全形势的发展变化，西北地区越来越成为汇集各方利益、影 响战略全局、关乎事业成败的重点地区，在我国政治、经济、外交和军事战略中的重要地位 将进一步凸显 [1]。然而, 当前西北地区大国强权、利益争夺和领土争端各种矛盾相互交织, “东突”、“民运”、“法轮功”邪教组织等敌对势力勾连破坏，“基地组织”、“伊斯兰国” 等国际恐怖组织辐射渗透, 恐怖活动范围不断扩大, 组织更加严密, 手段更加残忍, 反渗透、 反分裂、反颠覆斗争异常尖锐复杂。2015 年 12 月 27 日，第十二届全国人大常委会第十八次 会议通过的《中华人民共和国反恐怖主义法》明确指出，中国人民解放军、武装警察部队、 民兵组织, 依照相关法律、法规、命令, 根据反恐怖主义工作领导机构的部署, 防范和处置 恐怖活动, 从而在法律上确立了军队反恐的合法性和必要性。西北方向反恐作战, 是在《国 防法》、《反恐怖主义法》等法律范围内，紧紧依靠军队、警察和各级地方政府，广泛发动 各民族群众，通过各种手段打击和惩治暴力恐怖主义、宗教极端主义和民族分裂势力的非战 争军事行动，对于保持西北地区安全稳定、各民族群众团结幸福，维护我国主权、安全和发 展利益有着极其重大的现实意义。

\section{2 西北方向反恐作战空管保障主要任务}

西北方向反恐作战空管保障，是立足西北地区自然、社会和经济发展实际，以反恐作战任务 需求为牵引, 以保障运输机、直升机、无人机安全有序高效运行为重点, 由军地各级空管保 障单位相互协调共同完成。其主要任务包括：通过掌握飞行计划、监督飞行活动、组织管制 协调、实施飞行指挥等手段，保障军用运输机或被临时征用的民航飞机运送作战物资、装备 器材、后勤补给, 保障军用或警用直升机、无人机进行空中搜索监控、边境封控、警戒巡逻 和空中火力打击，保障电子战飞机、军用或警用医疗救援飞机进行电子干扰和战场救护，保 障作战飞机空中拦截或攻击遭恐怖分子劫持的民用航空器, 保障专机和重要任务飞行, 保障 民航班期飞行调整航路航线，绕开作战地带。

\section{3. 西北方向反恐作战空管保障特点及要求}

3.1 恐怖活动的隐蔽性、暴烈性要求空管保障应急性强，反应迅速 西北地区沟谷纵横、交通不便，恐怖分子为避免集中被歼，多采取小部、单独、分散行动， 活动隐蔽, 善于伪装; 恐怖活动诱因复杂、事发突然、难以预测, 短时间内容易造成社会恐 慌。此外，恐怖分子为了达成其目的，不惜孤注一掷，手段极端残忍，破坏性大 [2]。恐怖活 动的隐蔽性、突发性和暴烈性, 要求空管保障系统应急性强, 反应迅速, 确保在恐怖事件发 生后能够当机立断、果断处置。一是要求空管系统平战转换必须快速高效。空管部门必须结 合自身任务特点，制定切实可行的转换预案，明确转换的时机、程序和方法，确保平战转换 具有预见性、操作性和可行性。应根据反恐作战形势变化, 综合各方情报信息, 把握最佳转 换时机，一旦命令下达，迅速组织实施。此外，空管保障平战转换涉及指挥体制、部门职能、 工作重点等各个方面, 工作头绪多, 组织协调难, 必须统筹协调各方关系, 加强军民航各自 内部、军民航之间及与其他部门之间的协调。二是要求空管系统必须机动灵活。一方面, 空 管保障设备要结构轻便、功能完善、操作简单，能适应高寒山地地区作战环境和恐怖分子活 动特点, 应吸收借鉴美日等发达国家先进经验, 在研发机载式、车载式和便携式空管指挥终 端设备、空管卫星等方面加大科研投入, 实现装备保障灵活多样。另一方面, 空管人员综合 素质要高, 不仅要快速熟悉掌握本单位、本军种反恐作战用空需求, 还要灵活协调与其他单 位、其他军种的关系，保证快速准确地处理管制信息，以适应反恐战场快速发展的需要。

3.2 反恐环境的复杂性、敏感性要求空管保障适应性强，法规健全

一方面, 反恐环境具有复杂性。西北地区气候干燥, 地形复杂, 交通不便, 自然条件恶劣, 要求空管保障装备必须适应恶劣的气候和地理环境，具备良好的机动性和稳定性，确保在恐 
怖事件发生后能够迅速部署、果断处置; 该地区地表单一，植被较少，空管保障系统目标明 显, 容易暴漏, 要求空管装备必须具备较强的抗毁能力和快速修复能力, 保持较高的设备完 好率; 该地区民族杂居, 宗教信仰复杂, 经济落后, 战争动员潜力有限, 要求空管装备人员 必须适应该地区的社会和人文环境, 充分调动各种资源完成任务, 确保后勤补给的连续性稳 定性; 该地区地磁场扰动频繁, 空间电场复杂, 民用用频设备多, 电磁防护简单, 要求空管 装备必须具备较强的抗电磁干扰能力。除此之外, 管制人员在保障反恐作战任务时, 往往面 临生与死的严峻考验, 必须具备极强的心理控制和适应能力。另一方面, 反恐作战具有敏感 性。西北边境邻国较多, 与周边部分国家在领土方面还存在较大争议, 战时如何将恐怖分子 同人民群众、极端主义与宗教信仰区别开来, 如何将空管与空防有机统一起来, 实现边境地 带有效管控, 如何与相邻国家就军机过境问题、国际航路航线关启问题达成协商, 保证飞行 安全, 都需要相关的法规制度来约束。此外, 西方大国一直对我实施遏制、围堵战略, 插手 扶植 “三股势力”, 妄图破坏我和平稳定的发展形势, 我对西北地区实施反恐作战, 在目标 识别、武器选择等方面必须符合国际法精神, 避免给西方大国留下口实, 造成国际舆论的被 动。

\section{3 反恐作战的立体性、多样性要求空管保障技术性强, 手段先进}

一方面, 反恐作战呈现立体性。水平范围来看, 西北地区空域面积 335.24 万平方公里, 占全 国总面积的 $1 / 3$ 还多 [3]。据统计, 空域内仅国际航路航线就有 31 条, 国内航路航线则更为 密集。垂直范围而言, 反恐作战中各类运输机、直升机、无人机需要全维机动, 全域到达, 飞行活动覆盖了超低空、低空、中空、高空和超高空。时间范围而言, 反恐作战时间跨度长, 且对于单个作战任务, 也经常会出现跨昼夜、长航时飞行。另一方面, 反恐作战任务多样, 力量多元。既有空中封控、侦察搜索、对敌打击、电子干扰等作战任务, 又有力量投送、医 疗救援、物资补给等保障任务; 既要出动陆军、空军航空兵各类有人作战飞机、支援保障飞 机, 又要出动被军方临时征用的民用航空器。立体多维的作战空间, 多样化的作战任务, 要 求空管保障技术手段要敢于打破传统、锐意创新。在管制方式上, 改变程序管制为主, 雷达 管制为辅的局面, 加强顶层设计和规划, 加快相关基础设施建设, 在更大范围推广实施雷达 管制或 ADS/CPDLC。在保障模式上, 以固定式空管系统为主, 统筹发展卫星、机载、车载、 单兵空管保障系统。在管制技术上, 以高频、甚高频电台, 陆基导航台、测距台, 航管一次、 二次雷达为主, 加强卫星、数据链通信技术，星基、区域导航技术，北斗卫星、ADS-B 监视 技术的应用和普及。

\section{4. 西北方向反恐作战空管保障对策思考}

\section{1 理顺反恐作战空管组织体系}

反恐作战空管组织体系, 是在联合作战指挥体制框架下, 根据反恐作战特点需求确定的机构 设置、隶属关系和责权划分等组织制度, 是作战指挥系统的有机组成部分。应着力减少层级, 缩短指挥流程, 明确指挥权限, 理顺协同关系, 保证权威、精干、合成、高效。一是组建军 委联指反恐作战空管保障机构, 履行监控全国的空情信息, 为反恐作战提供情报保障, 与周 边国家协商空域使用, 对外发布禁航通告等职责。二是在战区联指成立反恐作战空管中心, 全面负责战时一切涉空作战行动, 统筹协调战区各方向空管保障工作, 对战区内所有用空单 位实施有效管控。三是依托战区各主要方向空管保障单位, 负责协调各军兵种用空需求, 监 控飞行动态, 解决飞行冲突, 防止航空器相撞和误击误伤。四是依托各作战部队空管保障单 位, 负责飞行计划处理、飞行情报编发、飞行动态监控和部分飞行指挥。五是根据需要, 在 战区层面组建若干空管机动分队, 平时隐蔽待战, 战时机动使用, 可用于定点清除、边境封 控等专项反恐作战任务, 弥补战时空管机动能力不足的缺陷 [4]。

\section{2 健全反恐作战空管运行机制}

一是完善信息融合共享机制, 应针对反恐作战特点, 统筹空情信息融合的顶层设计, 建立空 情信息融合分发制度, 整合空管情报信息和作战情报信息, 融合军民航空管信息, 实现军兵 
种之间、军地之间、军民航之间信息的互联互通。二是落实人员协调联络机制。落实好军兵 种之间互派联络员制度, 在战区层面统一协调, 及时处理各用空单位空域申请; 落实好军民 航之间互派联络员制度，协调处理军民航空域使用矛盾冲突; 落实好政府机构派驻联络员制 度, 增加公安、武警、民兵预备役等联络人员, 强化各级政府组织的快速有效协调功能。三 是健全军地联合会商机制。当前, 军方与地方、军航与民航之间的协商工作仍然停留在临时 沟通和部门协调层面, 效果不好, 力度不够。应围绕军事设施维护、战场资源管理、电磁频 谱管控、军民航联合运行等重大问题, 建立空军与民航、战区与地区民航和地方政府之间的 联合会商机制，规范协商的层级、时间、内容、方法，实现常态化、标准化运行。

\section{3 制定反恐作战空管法规标准}

空管法律法规影响和制约着空管活动, 是规范航空器有序运行的基本依据, 也是提高空中作 战效能的有力武器。一是加快推进航空立法工作, 将空域资源管理上升到法律层面加以规范, 确定空域资源的属性定位、使用权限、责任区分等问题，明确平时军民航空域资源规划使用 的责任和权力, 战时军民航空管联合运行方式, 紧急情况下军方接管民航指挥权的体制机制, 征用民用航空人员、航空器、机场设施、情报系统、通信导航和物资油料的实施方法等。二 是研究制定战时空管保障条令条例, 规范战时空管组织体系、体制编制、机构设置、指挥关 系、职责权利、工作流程, 明确战时空域划设、空域使用方法原则、空中管制权限和通报协 调规定，研究飞行计划制定、飞行调配原则方法、管制协调与移交、特情处置规则、管制指 挥、防相撞等相关理论。三是加强对国际法的研究与运用。熟悉掌握国际战争法、国际航空 法、空中交战规则等国际法规, 充分利用国际法中对反恐作战有利的条款, 规避不利因素, 力争在反恐作战中有理、有利、有节，防止因为误击误伤造成国际與论上的被动。

\section{4 发展反恐作战空管技术装备}

以反恐作战空管保障任务需求为牵引, 以功能完备、操作简便、结构轻便、机动灵活为要求, 进一步加强空管技术装备研究。一是要把握空管装备发展规律。坚持经济适用、规模适度的 发展理念, 既保持相对的独立性和完整性, 具备信息处理、信息集成、自动告警和辅助管制 等功能, 又兼顾未来发展, 具备较强的可拓展性 [5]。二是要优化空管装备技术体系。梳理现 有装备与实际需求之间的差距, 尽快攻克制约装备发展的关键技术, 解决 “看得见、连得上” 的问题。加强北斗卫星、ADS-B 等空管监视技术研究, 形成天基、空基、地基立体监视平台; 加强卫星通信、数据链通信等空管通信技术研究, 解决远程通信距离短、质量差等现实问题; 加强基于星基导航、区域导航等空管导航技术研究, 尽快实现由陆基导航系统向星基导航系 统的转换, 为反恐作战空中管制保障提供可靠的导航保障。三是构建空管装备应用体系, 按 照多军种任务来源、多样化任务类型、多平台保障模式构建空管应急装备应用体系, 为推动 空管应急装备技术发展提供强大系统支撑。四是推动空管应急装备军民融合式发展, 必须以 推动空管应急装备军民融合式发展为目标, 克服制约发展的制度性障碍, 加快军用和民用关 键技术的相互转化, 在装备功能与性能要求等方面建立适应于军民航协同发展的标准体系, 为构建军民融合式空管科研生产体系提供有益参考。

\section{5. 结论}

西北方向反恐作战空管保障要组建中央军委一战区一作战方向三级空管组织体系, 保证指挥 精干高效; 要健全信息共享、人员联络、军地会商运行机制, 确保指挥顺畅有序; 要加强法 律、法规、条例的制定和执行, 确保指挥合法守规; 要把握规律、锐意革新、坚定走军民融 合的空管装备发展路子，促进空管技术装备大发展大繁荣。

\section{References}

[1]. Li Jianyin. Combat Equipment Support Capacity Research in Plateau Region [M] Beijing: Military Science Press, 2015. 
[2]. Lai ceyi. An Analysis of Anti - terrorism Operation in Frontier Regions [J]. Journal of National University of Defense Technology, 2012. (6): 12-15.

[3]. Zeng Rongxin, Xu Jianjie, etc. Northwest military topography Summary [M]. Beijing: People's Armed Police Press, 2004.

[4]. Yang Jie, Shen Di, etc. Reflections on Strengthening the Capability-Building of Battlefield Air Traffic Control [J]. Air Force Military Academy, 2016. (4): 31-33.

[5]. Li jinji,Zhao yujian Thoughts on the Innovation and Development of Air Traffic Control Emergency Equipment of Air Force in the Future [J]. Air Force Military Academy, 2016. (3): 98-99. 